JOLANTA GOŁĄB-KOWALSKA

\title{
WYBRANE PIETY W MALOPOLSCE Z OKRESU ŚREDNIOWIECZA. ICH PROWENIENCJA, DZIEJE I WIZERUNEK
}

Celem niniejszego artykułu jest ukazanie proweniencji i dziejów wybranych, charakterystycznych, a także słynnych Piet z różnych zabytków architektonicznych, zabytków sztuki i innych obiektów, takich jak: kościoły, kapliczki przydrożne, szpital. Kluczową kwestią w tym artykule będzie także ukazanie zewnętrznego wizerunku Piet. Wykażę także analogie, podobieństwa i różnice w wizerunku Piet z Małopolski i innych terytoriów oraz miejscowości spoza państwa polskiego w okresie średniowiecza. Przedstawię tylko wybrane małopolskie Piety z różnych miejscowości, takie jak: Pieta Limanowska, Pieta w kościele pod wezwaniem Narodzenia Najświętszej Marii Panny w Czchowie, Pieta z Wojnicza, Pieta z Biecza (Opłakiwanie II), Pieta z dawnego Szpitala Ubogich w Bieczu, Pieta z Witkowic, Pieta ze Szczyrzyca, Pieta z Dobczyc. Wybrałam właśnie te Piety, które najbardziej wykazują analogie, podobieństwa i różnice między sobą i innymi rzeźbami pomimo, że pochodzą z różnych miejscowości Małopolski $\mathrm{z}$ okresu średniowiecza. Wykażę także pokrewieństwo, różnice omawianych w artykule Piet z różnymi rzeźbami i Pietami z innych terytoriów Polski i spoza państwa polskiego.

Przedstawiłam tylko wybrane Piety, zwłaszcza te, do których można znaleźć rozproszone informacje z naukowych publikacji i materiałów źródłowych. W niektórych opracowaniach i artykułach naukowych brak szczegółowych informacji o proweniencji, dziejach i wizerunku niektórych gotyckich Piet $\mathrm{z}$ okresu średniowiecza w Małopolsce. To skłoniło mnie do opracowania tego artykułu. Jedynie o Piecie Limanowskiej można znaleźć rożne, szczegółowe informacje w opracowaniach, artykułach i materiałach źródłowych. Dotychczas nie opracowano syntetycznego opracowania, artykułu o proweniencji, dziejach i całościowym wizerunku Piet w epoce średniowiecza z Małopolski. Stało się to także przyczyną powstania tego artykułu.

Innym, ale także ważkim celem opracowania tego artykułu było uzupełnienie, a także poszerzenie niektórych informacji o pochodzeniu, dziejach i wizerunku Piet małopolskich z materiałów źródłowych. Przeprowadziłam kwerendę wybra- 
nych akt parafii z Małopolski w Archiwum Diecezjalnym w Tarnowie. Z przeprowadzonej kwerendy wynika, że najwięcej informacji w aktach parafii można znaleźć o proweniencji, dziejach i wizerunku Piety Limanowskiej. O pochodzeniu Piety z Wojnicza i z Czchowa ( z Zapotocza) są niewielkie informacje. O pozostałych Pietach nie ma informacji w materiałach źródłowych akt parafii.

Bardzo przydatne w przygotowaniu niniejszego artykułu okazało się opracowanie Józefa Edwarda Dutkiewicza pt. Małopolska rzeźba średniowieczna 1300-1450 oraz jego artykuł pt. Nieznane rzeźby XIV-XVI wieku na terenie Małopolski Poludniowo-Zachodniej w Biuletynie Historii Sztuki i Kultury. Publikacje tego badacza były niezbędne przy przedstawieniu pochodzenia, dziejów i wizerunku różnych Piet. Opracowanie pt. Późnogotycka rzeźba drewniana w Małopolsce 1490-1540 było przydatne przy przedstawieniu Piety z Dobczyc. Skorzystałam także w dużym zakresie $\mathrm{z}$ informacji zawartych $\mathrm{w}$ artykułach opracowania monograficznego pt. Limanowa. Dzieje miasta 1945-1989, którego redaktorem jest Tomasz Biedroń i z artykułów zawartych w tomie IX Tarnowskich Studiów Teologicznych, z Pisma urzędowego diecezji tarnowskiej (Currenda) i Almanachu Ziemi Limanowskiej ( $\mathrm{nr} 26$ ). Te publikacje były niezbędne do przygotowania opisu Piety Limanowskiej w szerokim zakresie. Niezbędne okazały się również informacje o Pietach zawarte w opracowaniu pt. Wokót Wita Stwosza. Katalog wystawy w Muzeum Narodowym w Krakowie, którego redaktorem jest Krystyna Stefaniak. Wykorzystałam także informacje z Teki krakowskiej (V), której redaktorami są: Stanisław Kołodziejski i Roman Marciniak oraz z opracowania pod redakcją księdza Jana Rzepy pt. Kapliczki i krzyże przydrożne na terenie diecezji tarnowskiej". Skorzystałam także w mniejszym stopniu przy opisaniu innych Piet z informacji zawartych w opracowaniu pt. Sztuka ziemi krakowskiej, której redaktorami są Tadeusz Chrzanowski i Marian Kornecki. Wykorzystałam także niewielkie informacje o Pietach z artykułu Lecha Kalinowskiego i ze sprawozdania dr Józefa Edwarda Dutkiewicza z 1947 roku, zawarte w Pracach komisji historii sztuki. Skorzystałam także z ogólnych informacji o Pietach z artykułu Tadeusza Dobrzenieckiego pt. Średniowieczne źródta Piety, zawartego w opracowaniu pt. Treści dzieła sztuki. Materiały sesji Stowarzyszenia Historyków Sztuki.

Jedno z najbardziej popularnych w średniowiecznej sztuce przedstawień nazywa się Pietá. Ten włoski termin jest odpowiednikiem łacińskiego - Pietas, skrótu nazwy: Domina Nostra de Pietate, stosowanej w średniowieczu na oznaczenie siedzącej Marii, trzymającej na kolanach zmarłego Chrystusa. ${ }^{1}$ Pieta wyraża współudział Marii w dziele Zbawienia. ${ }^{2}$ Pierwsze przedstawienia Piety pojawiły się w Niemczech w pierwszej połowie XIV wieku. W okresie późnego średniowiecza Pieta została rozpowszechniona w całej Europie, stając się jednym z częstszych przedstawień dewocyjnych. Do jej wariantowych typów należą między in-

${ }^{1}$ T. Dobrzeniecki, Średniowieczne źródła Piety, w: Treści dzieła sztuki. Materiaty sesji Stowarzyszenia Historyków Sztuki, red. M. Witwińska, Warszawa 1969, s. 11, Zob. Pietá, w: Stownik sztuki, red. K. Gabryś-Cichacz, M. Goras, A. Małygi, R. Marcinka, M. Myślińskiego, W. Rostworowskiej, A. Siwka, M. Trafas - Wołoszyn, Kraków 2008, s. 405.

${ }^{2}$ Pietá, w: Stownik terminologiczny sztuk pięknych, red. K. Kubalska-Sulkiewicz, Warszawa 1996, s. 313. 
nymi Pieta corpusculum ( z Chrystusem przedstawionym jako dziecko) oraz Pieta anielska $z$ aniołami towarzyszącymi Matce Boskiej. ${ }^{3}$

Biskup Ordynariusz Jerzy Ablewicz w liście pasterskim z 11 sierpnia 1966 roku wyjaśnił treść nazwy rzeźby: „Pieta”, które znaczy także „,wierność”. „Maryja pozostała wierną Jezusowi aż do Jego krzyża i grobu. Stąd łatwo zrozumieć, że Pieta Limanowska była dla ludu polskiego źródłem jego wierności Bożej prawdzie w ciągu długich stuleci". ${ }^{4}$ Pietŕ - słowo pochodzi z języka włoskiego i oznacza miłosierdzie ( uwielbienie, cześć). W języku niemieckim nazywana jest Vesperbild, a to wskazuje na porę, w której owa scena się rozgrywa, to znaczy tuż przed zachodem słońca, gdy zdjęto ciało Chrystusa z krzyża i złożono na łonie swej Matki. ${ }^{5}$

Istnieją trzy poglądy na genezę Piety. Pierwszy z nich upatrywał źródło grupy Matki ze zmarłym Synem na kolanach w scenie Opłakiwania. Drugi, utrzymujący się stosunkowo długo w literaturze naukowej, wyprowadzał Pietę z trzech gatunków literackich: utworów lirycznych, epickich i mistycznych, opiewających ból, a nawet rozpacz Marii na Kalwarii. Pogląd ten jest jednak sprzeczny z podstawowymi założeniami łacińskiej mariologii średniowiecznej. Największy autorytet i uznanie zdobyło twierdzenie, że Pieta nie jest przedstawieniem wydarzenia, że jest to ahistoryczne, pozaczasowe przedstawienie dewocyjne, rezultat przekształcenia wyobrażenia siedzącej Marii z Dzieciątkiem. Pieta jest zarazem przedstawieniem dogmatycznym, ponieważ Maria, powodowana cnotą Pietas, trzymając ciało Chrystusa składa ofiarę ze swego Syna i w ten sposób dokumentuje swój udział w dziele Odkupienia. ${ }^{6}$

\section{Pieta z Wojnicza}

Za najstarszą małopolską rzeźbę drewnianą z początku XIV wieku uznana jest Pieta z Wojnicza, niewielka, w swym wyrazie archaiczna. ${ }^{7}$ Obecnie znajduje się w Muzeum Diecezjalnym w Tarnowie. ${ }^{8}$, ,Pieta Wojnicka” dawniej umieszczona była w kapliczce przydrożnej. Kapliczka usytuowana jest za fosa przy drodze obok parafii w Wojniczu. Kapliczka jest prostokątna, murowana, wykonana z cegły, otynkowana. Jest zamknięta półkoliście, wewnątrz sklepiona. Wyróżnia ją daszek siodłowy kryty dachówką. Obecnie wewnątrz kapliczki są oleodruki: tylko nad ołtarzykiem Pana Jezusa na krzyżu z końca XIX wieku, obraz Pana Jezusa w Ogrojcu ( nowszy oleodruk), obrazek Matki Bożej Częstochowskiej. Jest to

${ }^{3}$ Tamże.

${ }^{4}$ P. Bednarczyk, Parafia Matki Boskiej Bolesnej w latach 1945-1979, w: Limanowa. Dzieje miasta-1945-1989, t. 2, red. T. Biedroń, Kraków 2002, s. 443.

${ }^{5}$ J. Sz. Wroński, Stynna Pieta z Limanowej. Pani Nasza Limanowska, „Almanach Ziemi Limanowskiej", 7 (2006) nr 26, s.12.

${ }^{6}$ Dobrzeniecki, Średniowieczne, s. 12-13, Por. L. Kalinowski, Geneza Piety średniowiecznej, w: Prace Komisji Historii Sztuki, t. 10, red. A. Bochnak, Kraków 1952, s. 153-260.

${ }^{7}$ T. Chrzanowski, M. Kornecki, Sztuka Ziemi Krakowskiej, Kraków 1982, s. 108.

${ }^{8}$ J. E. Dutkiewicz, Matopolska rzeźba średniowieczna 1300-1450, Kraków 1949, s. 97. 
kapliczka bardzo stara, powstała w XVIII wieku. W aktach parafii Wojnicz brak jednak informacji o twórcy tej kapliczki. ${ }^{9}$ Powstanie tej gotyckiej Piety datuje się na pierwsze lata XIV wieku. ${ }^{10}$ Pieta $\mathrm{z}$ Wojnicza, jedno z najwcześniejszych dzieł plastyki polskiej, została przywieziona lub wykonana na miejscu przez wędrownego snycerza. ${ }^{11}$

Jest to rzeźba wykonana z drzewa. Rzeźba należy do grupy przyściennej. Jest wydrążona, o wysokości $70 \mathrm{~cm}$. Stan tej rzeźby jest dobry, ma drobne uszkodzenia. ${ }^{12}$ Rzeźba jest skomponowana ściśle frontalnie. Nawiązuje do monumentalnych, romańskich tronujących Madonn. Z kamiennym i jakby zastygłym wyrazem twarzy Maria prezentuje widzowi martwe ciało Chrystusa na wpół leżące na kolanach. ${ }^{13}$ Należy do typu przedstawień intymnych Opłakiwania, w których zgodnie z wypowiedzią św. Bernardyna ze Sieny Chrystus zmarły przedstawiony jest w małych wymiarach, jakby dziecko na łonie matki. Hieratyczność pozy, charakter płaskiej twarzy, przypominającej wzory sztuki wschodu, a przede wszystkim długość prosto ustawionych goleni, równe rozmieszczenie stóp i obiegająca dołem jak gdyby stożkowata kryza - oto cechy, które żywo przywodzą na myśl tradycje romańskie. Analogie łączą tę rzeźbę z figurą siedzącej Madonny w Muzeum w Kolonii z końca wieku XIII i bardziej odległe z figurami Madonn siedzących o zbliżonych wymiarach.

Pouczające są różnice, jakie dzielą od Piety wojnickiej najstarsze Opłakiwania saskie w swobodniejszym ukształtowaniu przestrzennym, miękkim traktowaniu form, zwłaszcza fałdów, mimo analogii w proporcjach, czy przedstawieniu małej figury Chrystusa, jak w Opłakiwaniu kamiennym w kościele Wszystkich Świętych w Erfurcie z czasu około roku 1390, Opłakiwaniu z czasu około roku 1365 w Muzeum Diecezjalnym w tejże miejscowości, czy Opłakiwaniu z małym

Chrystusem z lat 1360 - 1370 w Muzeum Miejskim (tamże). Przy tych analogiach datowanie zbliżonej w obrzędowym ujęciu Piety z Nellingsheim przez Bauma wydaje się spóźnione. Pełen dramatyczności intymny nastrój - bez analogii formalnych - przywodzi na myśl Pietę z Muzeum Prowincjonalnego w Bonn z początku wieku XIV. Mimo licznych tradycji romańskich liczne cechy, jak miękkie traktowanie fałdów i ujęcie figury Chrystusa, świadczą o przenikaniu już gotyckich prądów z Nadrenii. Wywarła wpływ na formowanie się Opłakiwania I z Biecza. ${ }^{14}$

Rzeźba ta zasługuje na szczególną uwagę także z uwagi na wybitne pomniejszenie postaci Jezusa. Ten typ ikonograficzny, zwany „Pieta corpusculum”, wzbo-

\footnotetext{
${ }^{9}$ Archiwum Diecezjalne w Tarnowie (dalej: AD w Tarnowie), zespół: Akta lokalne (parafialne), Wojnicz, sygn. LWXII, Parafia Wojnicz, Wojnicz, k. 1.

${ }^{10} \mathrm{~J}$. Rzepa, Kapliczki, figury i krzyże przydrożne na terenie diecezji tarnowskiej, Tarnów 1983, s. 721, AD w Tarnowie, zespół: Wojnicz, sygn. LWXII, Parafia Wojnicz, k. 1, Zob. J. Dutkiewicz, Małopolska rzeźba średniowieczna - Plastyka ruchoma do połowy XV wieku, w: Prace komisji historii sztuki, t. 9, red. A. Bochnak, Kraków 1948, s. 267.

${ }^{11}$ Dutkiewicz, Małopolska rzeźba, s. 98.

${ }^{12}$ Tamże, s. 97.

${ }^{13}$ Chrzanowski, Kornecki, Sztuka, s. 108.

${ }^{14}$ Dutkiewicz, Małopolska rzeźba, s. 97-98.
} 
gaca swą treść, symbolizując zarazem boleść matki opłakującej swe dziecko. Do tego samego typu nawiązuje druga, bardziej już zaawansowana stylistycznie Pieta, pochodząca $\mathrm{z}$ dawnego szpitala ubogich w Bieczu, a w kolejnym zabytku w Jawiszowicach - martwy Chrystus jest wielkości niemowlęcia. ${ }^{15}$

\section{Pieta Limanowska}

Ta słynna rzeźba pochodzi z parafii limanowskiej powstałej około 1513 roku. Założył ją Achacy Jordan, który wybudował też pierwszy kośció ${ }^{16}$. Pierwszy kościół w Limanowej zbudowany został przed rokiem 1527 (w latach 1510 - 1518) - dokładnego roku ustalić nie można ${ }^{17}$. Do 1577 roku opiekowali się nią Kanonicy św. Marka. ${ }^{18}$ Potem administrowany był niezmiennie przez księży diecezjalnych. Obecny kościół - trzeci z rzędu - powstał w latach 1910 - 1918, staraniem proboszcza księdza K. Łazarskiego. Jest murowany i w stylu secesyjnym. Nuncjusz F. Marmaggi napisał o nim, że to „ecclesia una de pulcherrimis totius Poloniae”. W tym to kościele, w głównym ołtarzu, znajduje się cudowna figura Matki Bożej Bolesnej. ${ }^{19}$ Figura Matki Bożej Bolesnej w Limanowej jest rzeźbą typu „Pietŕ”. Przedstawia Matkę Najświętszą siedzącą na ławeczce i trzymającą na kolanach umęczone Ciało Jezusa. ${ }^{20} \mathrm{Z}$ akt archiwalnych parafii limanowskiej (Sanktuarium Matki Boskiej Bolesnej w Limanowej) można się dowiedzieć, że ta starodawna Pieta pochodzi według Józefa Edwarda Dutkiewicza z lat 1350 - 1375, a więc wtedy, gdy powstała osada Wilmanow. Rzeźba nie została wykonana w wymienionej osadzie. $Z$ akt archiwalnych wynika, że historycy sztuki zgodnie orzekli, że figura ta pochodzi z drugiej połowy XIV wieku. Powstała w czasie rządów Kazimierza Wielkiego. Niektórzy historycy sztuki przesuwają czas powstania figury raczej na koniec XIV wieku, a więc na czasy, w których panowali Władysław Jagiełło i Jadwiga. Ostatecznie wnioskuję, że jest to rzeźba czternastowieczna. Potwierdzają to różne wzmianki o rzeźbie w aktach parafii limanowskiej. Twórca tej rzeźby jest nieznany. Nie ma żadnych wzmianek w aktach parafii o twórcy tej rzeźby. Nie ma także pełnych informacji, gdzie powstała ta rzeźba. Są różne opinie na temat powstania tej rzeźby. Jedno jest pewne, że figura ta nie pochodzi $\mathrm{z}$ warsztatów miejscowych. Rzeźba pochodzi z warsztatów śląsko - pomorskich. Do Limanowej dostała się z Węgier w okresie reformacji (według starych podań). Umieszczono ją najpierw na drzewie lipowym, a potem w drewnianej kaplicy pod wezwaniem Matki Boskiej Bolesnej w Mordarce, zbudowanej w XVIII wieku.

${ }^{15}$ Chrzanowski, Kornecki, Sztuka, s. 108-109.

${ }^{16}$ Bednarczyk, Limanowa - Matka Boża Bolesna, „Tarnowskie Studia Teologiczne”, 9 (1983) s. 193.

${ }^{17}$ L. Kowalski, Historia kultu łaskami stynacej figury Matki Boskiej Bolesnej w Limanowej, w: Currenda - Pismo urzędowe diecezji tarnowskiej, red. J. Rzepy i P. Bednarczyka, Tarnów 1957, s. 246.

${ }_{18}^{18}$ J. Rzepa, Rocznik Diecezji Tarnowskiej na rok 1972, Tarnów 1971, s. 290.

${ }^{19}$ Bednarczyk, Limanowa, s. 193.

${ }^{20}$ Tamże, s. 193. 
Kaplicę konsekrował w 1668 roku biskup M. Oborski. W roku 1743 i ostatecznie w 1753 roku na polecenie Kurii Krakowskiej figurę przeniesiono do kościoła parafialnego. ${ }^{21}$

Z informacji zawartych w artykule Józefa Szymona Wrońskiego pt.,,Słynna Pieta z Limanowej. Pani Nasza Limanowska" wynika, że omawiana rzeźba jest błogosławionym darem z zewnątrz, a więc importem. Józef Szymon Wroński tak pisze w artykule o tej Piecie: „Skąd przybyła, tego jeszcze nie rozstrzygnięto. Są przypuszczenia dwojakiego rodzaju: albo z Węgier, jak chce miejscowa tradycja, albo ze Śląska lub nawet z Północy ( z Pomorza). Józef Edward Dutkiewicz chciałby widzieć w rzeźbie limanowskiej cechy rzeźby śląsko - pomorskiej. Dzieła tego typu stanowią mniej lub bardziej udaną interpretację dzieł klasycznych, rzadko im dorównując, powstawały w latach 1300 - 1450". Wydaje się, że rzeźba jest ,interpretacją podobnego przedstawienia $\mathrm{z}$ Erfurtu, w śląskim wydaniu $\mathrm{z}$ tego okresu z Lubiąża lub w czeskim z Chebu". Magdalena. Kunze, z erfurckiego Angermuzeum potwierdziła tezę Józefa Edwarda Dutkiewicza. Przesunęła powstanie figury na koniec XIV wieku dlatego, że rozporządzała fotografią przed renowacją figury. Magdalena Kunze w liście do księdza dr Piotra Bednarczyka z 12 października 1961 roku tak pisze: „Jest rzeczą pewną, że już od wczesnego średniowiecza istniały silne związki handlowe i inne pomiędzy naszym miastem [Erfurtem - przyp. J. Sz. W.], a Węgrami. Jest zatem bardzo prawdopodobne, że Statua [Limanowska] została wykonana tutaj [w Erfurcie], dostała się na Węgry, a stamtąd do Polski. Przywędrowała tu prawdopodobnie w czasach reformacji, kiedy „oczyszczano” kościoły z przedstawień maryjnych i została przygarnięta przez zawsze wierny Marii lud limanowski. Natomiast przytoczona przez Nowakowskiego wiadomość o węgierskim pochodzeniu figury nie znajduje potwierdzenia $\mathrm{w}$ analizie stylistycznej, chociaż nie wykluczone, że powstała w kręgu wpływów śląsko-czesko niemieckich. ${ }^{22}$

Istnieje stara tradycja, osnuta mgłą legend, że figura - mimo innego warsztatu powstania - dostała się do Limanowej z Węgier. W oparciu o nią powstały dwie hipotezy. Według jednej z hipotez Serwici jeszcze przed reformacją mieli przenieść tę figurę w okolice Limanowej, a potem przenosząc się z jakiegoś powodu gdzie indziej, figurę przekazali miejscowemu dworowi w Mordarce. Według drugiej hipotezy figurę przywieźli do Polski czciciele Matki Bożej Bolesnej z Węgier, w związku z reformacją w tym kraju. Mogło to być około 1545 roku, kiedy szlachta węgierska na synodzie w Erdöd opowiedziała się za kalwinizmem. Możliwe, że figurę złożono najpierw w jakiejś parafii ziemi sądeckiej, a gdy i w te strony przyszło nowinkarstwo religijne, ukryto ją w Mordarce. $Z$ hipotez wynikają różne wnioski. Figura była już w Mordarce w czasie reformacji - świadczą o tym legendy o złej pani heretyczce. Według drugiej hipotezy figura znalazła się w Mordarce poza proboszczem parafii, za pośrednictwem dworu. Umieszczona zostaje najpierw na lipie, a potem w drewnianej kapliczce. Figura znalazła się w Mordarce już ze sławą cudowności, zgodnie z cytowaną pieśnią:

${ }^{21} \mathrm{AD}$ w Tarnowie, zespół: Akta lokalne (parafialne), Limanowa - kapliczki, koronacja, sygn. LLVI, Sanktuarium Matki Boskiej Bolesnej w Limanowej, k. 2, Zapoznanie, k. 71, 72.

${ }^{22}$ Wroński, Stynna Pieta z Limanowej, s. 12, Bednarczyk, Limanowa, s. 194. 
Przybyłaś, wieść niesie, z Węgier przed wiekami

Uchodząc przed mściwą niedowiarka ręką,

Przybyłaś do Polski już sławna cudami

Wzeszłaś nam w Mordarce przejasną jutrzenką...

Po XVII wieku historia Piety jest już bardziej udokumentowana. Pieta limanowska jest rzeźbą ludową. Jest $\mathrm{w}$ wysokim stopniu uszlachetniona, wzorowana na dziełach sztuki. W ciągu wieków była kilkakrotnie przemalowywana. Pierwotna jej polichromia to: turkusowo - niebieski płaszcz Matki Bożej, suknia czerwona, bardzo wyrazista karnacja ciała Pana Jezusa. Cała figura ma niezwykłą kompozycję. Można powiedzieć, że doszło w XVII wieku do „eksplozji” jej kultu. Od chwili powstania związał się z nią kult Matki Bożej Bolesnej. W kaplicy w Mordarce zyskała sławę cudowności. Wyrazem tego stało się źródełko, które wytrysło obok figury. $Z$ dalekich stron poczęli przybywać do Mordarki pątnicy, by prosić o łaski, a za otrzymane składali nieraz bogate wota. Ruchowi temu patronowali właściciele Mordarki - zwłaszcza Gurzańscy i to niezależnie od proboszcza parafii $^{23}$.

Jednak za czasów proboszcza Sebastiana Liszkiewicza w roku 1706 wpłynęła skarga do Konsystorza biskupiego w Krakowie, że w kapliczce tej lud się gromadził tłumnie nie tylko z parafii limanowskiej, ale i z całej okolicy. Parafianie limanowscy opuszczali w niedzielę i uroczyste święta kościół swój macierzysty i zbierali się na nabożeństwo w kapliczce, w której nieznani księża, dotknięci cenzurami kościelnymi, a nieraz apostaci, odprawiali nabożeństwa. Były rozgłaszane cuda, których wiarygodność nie została sprawdzona i może to być fraus diabolica, że wiara w urojone cuda szkodzi i na szwank naraża prawdziwość cudów, podkopuje religię i wiarę. Konsystor zarządził zamknięcie kaplicy dopóki sprawa nie zostanie zbadana. Polecił Józefowi Jordanowi, archidiakonowi Kolegiaty Sądeckiej, proboszczowi w Podegrodziu i dziekanowi sądeckiemu, do których wówczas kościół w Limanowej należał, a nawet w dalszych kościołach poza dekanatem, aby nikt pod grozą kar kościelnych nie ważył się nawiedzać kaplicy. Kult Matki Boskiej Bolesnej, mimo tak surowego zakazu gromadzenia się w kaplicy, bynajmniej nie ustał, ale przeciwnie - wydawał się wzrastać, a świadczą o tym akta wizytacji z roku 1727, w których znajduje się wzmianka Oficjała sądeckiego, księdza Józefa de Zakliczyn Jordana, kanonika Katedry krakowskiej, a archidiakona sądeckiego, dotycząca kaplicy w Mordarce. W 1742 roku proboszcz wniósł skargę do Sądu w Nowym Sączu w tej sprawie i prawdopodobnie, żeby postawić Sąd przed faktem dokonanym, zarządził uroczystą procesję do kaplicy po zakończeniu misji parafialnych i po odprawionym nabożeństwie w kaplicy zabrał statuę Matki Boskiej Bolesnej i przeniósł ją do kościoła parafialnego. Potem Górzański ze swoimi ludźmi wybiwszy okno w kościele, zabrał figurę Matki Boskiej i umieścił ją z powrotem w kaplicy. W 1753 roku na skutek decyzji księdza biskupa Załuskiego, po odprawionych misjach parafialnych do kaplicy w Mordarce udała

${ }^{23}$ AD w Tarnowie, zespół: Akta lokalne (parafialne), Limanowa - kapliczki, koronacja, sygn. LLVI, Zapoznanie, k. 72, Sanktuarium Matki Boskiej Bolesnej w Limanowej, k. 2, Bednarczyk, Limanowa, s. 195. 
się procesja. Statua Matki Boskiej, słynąca cudami została przeniesiona uroczyście po raz drugi i umieszczona w kościele parafialnym. W 1769 roku pożar zniszczył wszystkie budynki, spalił się również i kościół parafialny, ocalała tylko cudem statua Matki Boskiej Bolesnej. Przeniesiono ją znowu do kaplicy w Mordarce, gdzie tymczasem odbywały się nabożeństwa parafialne i dopiero w roku 1774 sprowadzono ją do prowizorycznie zbudowanej kaplicy w Limanowej i umieszczono w nowym kościele pod wezwaniem Matki Boskiej Bolesnej.

Kult Matki Boskiej Bolesnej stał się żywszy, a świadczyły o tym coraz to nowe wota, licznie zamawiane Msze święte o uproszenie różnych łask lub też na podziękowanie za otrzymane dobrodziejstwa ze strony ludzi nawet z odległych parafii. O tym kulcie świadczyły liczne pielgrzymki i tłumy wiernych, garnących się na trzy doroczne odpusty: Matki Boskiej Bolesnej w Wielkim Poście, w Zielone Święta oraz Matki Boskiej Różańcowej. O głębokim kulcie Matki Bożej świadczą także nabożne pieśni ku Jej czci układane przez ludowego poetę, niejakiego Szymona Dutkę z Mordarki, a śpiewane przez szerokie rzesze ludu ${ }^{24}$.

Ostatnio rzeźba została poddana odnowieniu, usunięto z niej naleciałości wieków, zwłaszcza ostatnią dziewiętnastowieczną polichromię. Wówczas przywrócono jej wygląd pierwotny ${ }^{25}$. Figura Matki Boskiej zachowała się w dobrym stanie między innymi dzięki konserwacjom przeprowadzonym pod fachowym okiem. Ostatnia z nich, wykonana przez Annę i Wacława Szymborskich z Krakowa, miała miejsce przed koronacją, to jest 40 lat temu ${ }^{26}$.

Ksiądz prałat Ludwik Kowalski chciał doprowadzić do koronacji Piety Limanowskiej. Przygotowanie do tej uroczystości było podwójne: materialne i duchowe. Na przygotowanie materialne składało się: odnowienie Statuy Matki Boskiej Bolesnej i przebudowa Wielkiego Ołtarza. W sprawie odnowienia figury władze konserwatorskie (prof. Kozłowski) opowiadały się albo za całkowitym usunięciem polichromii i pozostawieniem figury w surowym stanie, albo pozostawieniem polichromii $\mathrm{w}$ dotychczasowym stanie $\mathrm{z}$ niewielkimi zmianami. Ksiądz prałat Kowalski zawiózł figurę do pracowni konserwatora Wacława Szymborskiego i ten dokonał gruntownej odnowy figury w1965 roku. Wiele dyskusji wśród parafian wywołała także przebudowa Wielkiego Ołtarza. Dużo wysiłków i czasu pochłonęło wykonanie wnęki oraz mechanizmu do odsłaniania i zasłaniania cudownej Statuy. Wykonali to wszystko bezinteresownie Rafał Bednarczyk z Franciszkiem Jasicą, Franciszkiem Dutką i Janem Klosem. W przygotowaniach duchowych, tak jak w Limanowej, jak i w całej diecezji odczytano w maju 1965 roku nauki o Matce Bożej Bolesnej pt. „Matka Boża Bolesna”w obliczu koronacji Piety Limanowskiej. Duże wrażenie zrobiły opisy łask przypisywane Matce Boskiej Limanowskiej. Ściągały one do Limanowej wielu pątników pojedynczych i grupowych. Bezpośrednie przygotowanie do koronacji dały misje parafialne, przeprowadzone przez księdza Olgierda Kokocińskiego, ze Zgromadzenia XX Filipinów, w dniach od 23 kwietnia do 1 maja 1966 roku. Zapowiedzią uroczystości

${ }^{24}$ Kowalski, Historia kultu łaskami, s. 248-250.

${ }^{25} \mathrm{AD}$ w Tarnowie, zespół: Akta lokalne (parafialne), Limanowa - kapliczki, koronacja, sygn. LLVI, Zapoznanie, k. 72.

${ }^{26}$ Wroński, Stynna Pieta z Limanowej, s. 11. 
koronacyjnej w Limanowej był list pasterski biskupa Jerzego Ablewicza z 11 sierpnia 1966 roku. W liście tym biskup Ordynariusz podkreślił, że Figura Limanowska pozwala nam przynajmniej w części poznać trzy wielkie milenijne tajemnice: tajemnicę naszej tysiącletniej wierności prawdzie, szlachetności życia i pociechy w cierpieniu".

Na uroczystość koronacyjną przybyło wielu biskupów. Biskup ordynariusz Jerzy Ablewicz swoje powitalne przemówienie zakończył takimi słowami: „Kiedyś nasz wieszcz Zygmunt Krasiński w chwilach ciężkich przyzywał Marię Królowę Polski, Królowę Aniołów, Lilię bez zmazy, Gwiazdę poranną mieczem boleści siedmiokrotnie ranną. Przyzywał, by dla narodu polskiego była Aniołem Opiekuńczym - jak pisał - teraz i na wieki. W dniu dzisiejszym my dzieci Diecezji Tarnowskiej przyzywamy Maryję Gwiazdę poranną mieczem boleści siedmiokrotnie ranną: Limanowska Pani, Matko nasza droga, idziemy do Ciebie, prowadź nas do Boga - przez dni, lata i wieki drugiego naszego tysiąclecia, by ono było również święte jak pierwsze, a przez to szczęśliwe jak pierwsze”. Kazanie podczas uroczystości milenijnej i koronacyjnej wygłosił arcybiskup Karol Wojtyła. Aktu koronacji dokonał ksiądz arcybiskup metropolita krakowski Karol Wojtyła w towarzystwie księdza biskupa ordynariusza Jerzego Ablewicza i biskupa Karola Pękali. ${ }^{27}$ Karol Wojtyła mówił wówczas o wizerunku Piety: „Stwierdzają znawcy sztuki, że Jezus, który spoczywa na kolanach, na łonie swej Matki, chociaż dorosły mężczyzna, jest przecież od Niej mniejszy; jak gdyby w tej swojej maleńkości raz jeszcze chciał wyrazić, uprzytomnić Swej Matce narodzenie w Betlejem." ${ }^{28} \mathrm{~W}$ imieniu własnym i swoich następców na urzędzie proboszcza w Limanowej, ksiądz Ludwik Kowalski złożył następującą przysięgę: „Przysięgam i ślubuję, że pilnie strzec będę Cudownej Figury Matki Bożej Bolesnej, która od czterystu lat jest otaczana czcią i miłością przez wiernych tej parafii i całej Limanowszczyzny, a za chwilę ma być ukoronowaną koroną papieską". Ksiądz prałat Ludwik Kowalski odszedł na emeryturę, pozostając w parafii limanowskiej nadal, jako rezydent, gdzie zmarł 18 października 1983 roku. Został pochowany na cmentarzu parafialnym. W dziesiątą rocznicę jego śmierci umieszczono na bazylice limanowskiej, obok grobu księdza Łazarskiego, następujący napis na płycie z brązu:,Gorliwie szerzył kult cudownej figury Matki Boskiej Bolesnej, doprowadził do Jej koronacji, ofiarnie bronił słusznych praw Kościoła limanowskiego w czasach komunistycznych. Pozostał w pamięci Limanowian jako troskliwy duszpasterz i gorący patriota. Wdzięczni parafianie"22.

Dwa tygodnie po zamachu na życie Ojca św. Jana Pawła II, w nocy z 26 na 27 maja 1981 roku, dokonano w Limanowej kradzieży korony Matki Bożej Bolesnej. Zabezpieczenie figury po pierwszej koronacji okazało się niewystarczające. Skradziona korona była srebrna, pozłacana, z kamieniami syntetycznymi, ale dla czcicieli Matki Bożej Bolesnej wartość tej korony miała o wiele większy wymiar, bo wymiar religijny. Kradzież korony Matki Boskiej Bolesnej przeżyła boleśnie nie tylko parafia, ale cała ziemia limanowska. Po tym smutnym wydarzeniu ksiądz

\footnotetext{
${ }^{27}$ Bednarczyk, Parafia Matki Boskiej Bolesnej, s. 444-445.

${ }^{28}$ Bednarczyk, Limanowa, s. 194.

${ }^{29}$ Bednarczyk, Parafia Matki Boskiej Bolesnej, s. 442-447.
} 
proboszcz przystąpił do zabezpieczenia Piety Limanowskiej, między innymi sprawiono nową zasłonę do głównego ołtarza - odlew z brązu przedstawiający Chrystusa na krzyżu, projektu Józefa Potępy, profesora Akademii Sztuk Pięknych w Krakowie. Zainstalowana została także szyba pancerna chroniąca dostępu do Piety, sprowadzona z USA dzięki staraniom księdza Mariana Tyrki ${ }^{30}$. Po tej dekoronacji, Limanowa stała w obliczu rekoronacji, której miał dokonać w Roku Jubileuszu Odkupienia w 1983 roku, po raz drugi ten sam koronator. Teraz już jako Papież Jan Paweł II ${ }^{31}$.

W ostatniej chwili Jan Paweł II zadecydował, że nie tylko poświęci korony, ale dokona rekoronacji w Krakowie. Wielką rolę w przygotowaniu koron odegrali państwo Stanisława i Wiesław Redelbachowie - złotnicy z Limanowej, wyrażając gotowość wykonania nowych koron bezinteresownie ( jako wotum dla Matki Bożej). Wiesław Redelbach stwierdził: „korona dla Matki Bożej Limanowskiej będzie największym dziełem mojego życia". 22 czerwca 1983 roku szum oklasków zwiastował przyjazd Ojca świętego. Rozpoczęła się papieska Msza święta. W czasie procesji z darami ołtarza limanowianie wręczyli Ojcu świętemu srebrny odlew figurki Matki Bożej Bolesnej Limanowskiej. Po Komunii świętej nastąpił moment poświęcenia koron i włożenia ich na skronie Chrystusa i matki Bożej. W tej uroczystej chwili najbliższej Ojca świętego był ksiądz proboszcz Józef Poręba. Pomagał Ojcu świętemu w dokonaniu aktu założenia koron. Na ołtarzu papieskim był również obecny ksiądz, biskup Piotr Bednarczyk. Po dokonaniu aktu rekoronacji ordynariusz tarnowski Jerzy Ablewicz złożył podziękowania Ojcu świętemu. Papież Jan Paweł II wypowiedział wówczas takie słowa: „Pod koniec mojej pielgrzymki [...] wypadło mi jeszcze przyozdobić po raz wtóry królewskim diademem Figurę Matki Bożej Limanowskiej, słynnej Piety z Limanowej [...] Ukoronowanej Matce mówimy słowami pieśni Wiary ojców bronić będziemy pod tym znakiem". Po odjeździe Ojca świętego z Błoni krakowskich, centrum zainteresowania stała się ukoronowana Figura Matki Bożej Bolesnej. Podchodzili i ze czcią całowali figurę: kardynałowie, biskupi oraz kapłani. To samo chciały uczynić tysięczne rzesze wiernych uczestniczących we Mszy papieskiej. Ukoronowana Matka Boża Limanowska została przeniesiona do kościoła OO. Karmelitów na Piasku w Krakowie, gdzie pozostała do soboty 25 czerwca 1983 roku. Figura ta odbyła swoistą peregrynację przez 7 kościołów w różnych parafiach: kaplicę sióstr Szarytek w Krakowie przy ulicy Warszawskiej, kościoły w Mszanie Dolnej, Szczawie, Kamienicy, Łącku, Jazowsku, klasztor sióstr Klarysek w Starym Sączu, gdzie siostry przy cudownej figurze modliły się całą noc. Natomiast uroczysty ingres Matki Bożej Bolesnej do kościoła limanowskiego odbył się w niedzielę 26 czerwca. Przed kościołem został wybudowany ołtarz polowy pod kierunkiem księdza Mariana Tyrki. W uroczystości ingresu wziął udział ksiądz, biskup Ordynariusz Jerzy Ablewicz, który wygłosił kazanie. Uroczystość zakończyła się bło-

${ }^{30}$ J. Poręba, Parafia Matki Boskiej Bolesnej w Limanowej w latach 1979-1989, w: Limanowa. Dzieje miasta - 1945-1989, t. 2, red. T. Biedroń, Kraków 2002, s.

${ }^{31}$ Bednarczyk, Limanowa, s. 200. 
gosławieństwem cudowną statuą Matki Bożej Bolesnej, którego dokonali księża biskupi i kustosz sanktuarium ${ }^{32}$.

Limanowska Pieta jest rzeźbą niezwykle oryginalną, chociaż na wpół konwencjonalną (obok partii doskonałych ma partie mniej artystycznie dopracowane). Przedstawia bolejącą Matkę, trzymającą na kolanach Chrystusa o znacznie pomniejszonych w stosunku do Maryi rozmiarach. Ten typ Piety zwie się potocznie Pietą - Radosną, a zgodnie $\mathrm{z}$ terminologią artystyczną corpusculum ${ }^{33}$.

Pieta limanowska jet rzeźbą wysoką. Rzeźba ma około $90 \mathrm{~cm}$ ( z koroną dochodzi do $1 \mathrm{~m}$ ), u podstawy ma 52, $5 \mathrm{~cm}$ szerokości. Jest wykonana $\mathrm{z}$ jednolitego pnia lipowego, z odwrotnej strony wydrążona i zasłonięta deszczułką z drzewa lipowego o sylwecie odwrotnej strony rzeźby ${ }^{34}$.

Rzeźba przedstawia Matkę Boską siedzącą na podwyższeniu i trzymającą na kolanach martwe ciało Jej Syna, ułożone ukośnie do postawy Marii. Matka prawą ręką podtrzymuje barki Jezusa Chrystusa, a lewą ręką obejmuje Go w pasie. Głowa w cierniowej koronie lekko odchylona w dół, jak u człowieka, który śpi. Jego usta są lekko otwarte. Ręce ułożone są równolegle. Prawa ręka oparta o kolano Matki, widać w niej otwór otoczony promieniami. Podobna rana widnieje w prawym boku. Lewa ręka Chrystusa kryje się pod lewą ręką Marii, tak, że rany w niej nie widać. Nogi Chrystusa opadają prostopadle na dół. Ciało Chrystusa jest nagie, z opaską na biodrach. Ma barwę ciała ludzkiego, włosy na głowie i czarną brodę. W boku prawym, na ręce prawej i na obydwu nogach widać pozłocone promieniste nimby. Perisonium jest koloru białego płótna. Cała postać Chrystusa jest nieproporcjonalnie mała w stosunku do wielkości Marii. Zminiaturowany Chrystus nie robi jednak wrażenia dziecka, ale dorosłego mężczyzny. Maria ubrana jest w czerwoną suknię, głowę Jej pokrywa welon, który przedłuża się w płaszcz o kolorze turkusowym, zarzuconej w obfite fałdy na kolana. Spod płaszcza widać końce stóp ukrytych w pantoflach. Głowa Maryi pochylona jest w bok, ku Chrystusowi, ale oczy patrzą w dal. W panieńskich rysach twarzy Marii widać ogromny spokój. Odzwierciedlają prawdziwe dostojeństwo cierpienia z pełnym poddaniem się woli Bożej. Jest to obraz tej samej Matki, która przed chwilą „stała” pod krzyżem $^{35}$.

Ciekawie o wizerunku Piety Limanowskiej pisał ksiądz prałat Tadeusz Bukowski.

W artykule Józefa Szymona Wrońskiego o Piecie Limanowskiej zawarty jest opis rzeźby księdza Tadeusza Bukowskiego. Ksiądz tak opisywał Pietę: „Nasza rzeźba została wykonana z jednolitego pnia drewna lipowego, jest polichromowana, na odwrocie wydłutowana. Anonimowy artysta przedstawił postać Marii $\mathrm{w}$ ujęciu frontalnym, siedzącą na ławie i trzymającą w ramionach martwe ciało

${ }^{32}$ Poręba, Parafia Matki Boskiej Bolesnej, s. 449-451.

${ }^{33}$ Wroński, Stynna Pieta z Limanowej, s. 12-13, J. Sz. Wroński, Bazylika Matki Boskiej Bolesnej w Limanowej, Limanowa 2001, s. 140.

${ }^{34} \mathrm{AD}$ w Tarnowie, zespół: Akta lokalne (parafialne), Limanowa - kapliczki, koronacja, sygn. LLVI, Zapoznanie, k. 71; Bednaczyk, Limanowa, s. 193.

${ }^{35}$ AD w Tarnowie, zespół: Akta lokalne (parafialne), Limanowa - kapliczki, koronacja, sygn. LLVI, Zapoznanie, k. 71. Por. Bednarczyk, Limanowa, s. 193. 
Syna. Podstawę kompozycji rzeźbiarskiej wyznacza obrys ławy, ale w górnej części dzieła artysta wyraźnie odchodzi od osi kompozycji dla wyrażenia gestu pochylenia się Matki nad ciałem Syna, dla spotęgowania wrażenia pewnego wysiłku w podtrzymywaniu ciążącego martwego ciała. Twarz Marii o czole szerokim, wypukłym i wysokim, o wyraźnie zarysowanych łukach brwiowych..., oczy zdają się być wpatrzone w dal, gdzieś ponad martwym ciałem Chrystusa, co potęguje wrażenie skupienia, niemego trwania w bólu..., usta drobne, delikatnie rozchylone w lewym kąciku, jakby ujawniały nie wypowiedziany ból matczynego serca. Efekt odkrycia czoła Marii i tak zakomponowane spojrzenie Jej oczu wraz z wyrazem ust - to skuteczna próba oddania wizji mądrości cierpienia: cierpienia ukrytego, nie krzykliwego..., chociaż Bolesna mogłaby wykrzyczeć swój ból słowami Jeremiasza: „Wszyscy, co drogą zdążacie, przypatrzcie się, czy jest boleść, jako boleść moja".

Rzeźba przetrwała do naszych czasów w dobrym stanie; zawdzięczać to należy rozwiniętemu kultowi, jakim ją otaczano w Beskidzie Wyspowym, w całej Diecezji Tarnowskiej i szeroko poza nią ${ }^{36}$.

Pieta znajduje się za szybą kulodporną. Warto zwrócić uwagę na zasłony ołtarza. Jedną z nich, zamówioną przez księdza proboszcza - kustosza limanowskiego sanktuarium Józefa Porębę, projektował prof. Józef Potępa z Akademii Sztuk Pięknych w Krakowie. Odlew w brązie przedstawia Chrystusa na krzyżu z wzniesionymi rękami (wypukłorzeźba), na tle panoramy jerozolimskiej (płaski relief) - wpływ krucyfiksu Wita Stwosza z bocznego ołtarza w Kościele Mariackim w Krakowie. Pomiędzy cokołami kolumn znajduje się pozłacane tabernakulum, wykonane w typie architektury ołtarza i posiadające w złoconych medalionach dwie sceny maryjne: Zwiastowania - radosną i Zmartwychwstania - chwalebną. Tabernakulum fundował ksiądz Jan Rachwał z Limanowej, a wykonała artystkarzeźbiarka Joanna Czyżowska - Sułkowska z Limanowej. ${ }^{37}$

\section{Pieta z Biecza (Opłakiwanie Chrystusa II)}

W kościele farnym, w powiecie gorlickim mieściła się Pieta z Biecza (Opłakiwanie II). Obecnie Pieta znajduje się w Muzeum Diecezjalnym w Tarnowie ${ }^{38}$ Kopia Piety z Biecza znajduje się w sądeckiej bazylice św. Małgorzaty w kaplicy wieczystej adoracji. ${ }^{39}$ Rzeźba pochodzi z lat 1380 - 1400. Rzeźba jest wykonana z drzewa. Jest rzeźbą przyścienną, wydrążoną o wysokości $103 \mathrm{~cm}$. Jest rzeźbą spróchniałą. Ma liczne uszkodzenia: brak głowy i nóg Chrystusa.

Tak jak Opłakiwanie I z Biecza i z Wojnicza, przedstawia Marię trzymającą na kolanach małego Chrystusa. Różni się od nich całkowicie ujęciem plastycznym, a pełnym dramatycznej treści wyrazem zalicza się do czołowych dzieł plastyki średniowiecznej w Małopolsce. Opłakiwanie II z Biecza zostało wykonane

\footnotetext{
${ }^{36}$ Wroński, Stynna Pieta z Limanowej, s. 12.

${ }^{37}$ Tamże, s. 11.

${ }^{38}$ Dutkiewicz, Małopolska rzeźba, s. 143.

${ }^{39}$ E. Storch, Pieta ze Znamirowic, „Bethania”, nr 4 (118) z kwietnia 2005 roku, s. V.
} 
w kraju, być może przez snycerza przybyłego ze Śląska lub Pomorza. Należy do rzędu najstarszych typów ujęcia Piety, jak z Lubiąża na Śląsku z czasu około roku 1370 oraz reprezentowanych w Niemczech przez rzeźby: z Veste Koburg z lat 1320 - 1330, Fritzlar z połowy wieku XIV, z kościoła urszulanek w Erfurcie i wspomnianą już z Muzeum Katedralnego tamże, z którą zwłaszcza wiąże ją treść wyrazu duchowego, podobieństwo proporcji, charakter, ruch i wyraz twarzy.

Z omawianych tu rzeźb, Opłakiwanie II z Biecza wiąże się szczególnie pod względem układu przestrzennego, proporcji, a nawet technicznego opracowania mas plastycznych i szczegółów z rzeźbami z powiatu limanowskiego, z Limanowej, a do pewnego stopnia i z Chrystusem tronującym z Biecza. $Z$ drugiej strony nie jest wykluczone - widoczne w redakcji dolnej partii - oddziaływanie figurek jasełkowych z klasztoru klarysek krakowskich ${ }^{40}$.

\section{Pieta z dawnego Szpitala Ubogich w Bieczu}

Pieta pochodzi z dawnego Szpitala Ubogich. Szpital mieścił się w murowanym budynku na wyniosłym wzgórzu w Bieczu ${ }^{41}$. Obecnie rzeźba mieści się w Muzeum Narodowym w Krakowie. Rzeźba pochodzi z drugiej ćwierci XIV wieku. Rzeźba jest wykonana z drzewa. Należy do grupy przyściennej. Jest rzeźbą wydrążoną, o wysokości $76 \mathrm{~cm}$. Stan tej rzeźby jest dobry. Rzeźba łączy się w ogólnym układzie i podobieństwie szczegółów, jak głowa Madonny, ruch rąk, figura Chrystusa, opracowanie spodu i stóp - o luźniejszych już tradycjach z Pietą z Wojnicza. Pietę z dawnego Szpitala Ubogich w Bieczu łączy z Pietą z Wojnicza bardziej malarskie i swobodne traktowanie formy, żywy ruch fałdów. $\mathrm{Na}$ tej płaszczyźnie bliższe analogie łączą to dzieło z Opłakiwaniem z kościoła Wszystkich Świętych i Muzeum Miejskiego w Erfurcie, jak również z Opłakiwaniem z Deggingen ${ }^{42}$.

\section{Pieta z Witkowic}

Rzeźba ta znajduje się w witkowickim kościele. Jest to średniowieczny, drewniany kościół pod wezwaniem św. Doroty. W tym kościele w Witkowicach przetrwała do dzisiaj niewielka rzeźba gotycka przedstawiająca św. Dorotę, mieszcząca się w zaimprowizowanym ołtarzyku. Marian Kornecki, autor artykułu pt. „Średniowieczna Pieta z Witkowicach" opisuje jak odnalazł rzeźbę.

W 1970 roku zniósł ze strychu kościoła witkowickiego dużych rozmiarów rzeźbę Marii opłakującej Chrystusa. Według Mariana Korneckiego jest to zabytek o niezwykłej wymowie ideowej i formalnej, budzący odruchowo jakby sprzeczne odczucia. Marian Kornecki w artykule o „Piecie w Witkowicach” tak pisał po odnalezieniu rzeźby: „Jest to rzeźba o potężnym dramatyzmie, przenosząca w at-

\footnotetext{
${ }^{40}$ Dutkiewicz, Małopolska rzeźba, s. 143.

${ }^{41}$ Dutkiewicz, Małopolska rzeźba, s. 98, T. Ślawski, Biecz i okolice, Warszawa 1973, s. 33.

${ }^{42}$ Dutkiewicz, Małopolska rzeźba, s. 98.
} 
mosferę dzieł głębokiego średniowiecza, od razu budząca określone skojarzenia, ale zarazem nie wolna od narzucających się znamion prymitywizmu, co podkreślał stan zachowania, uszkodzenia substancji i faktur, oczywiste przemalówki”. Według Mariana Korneckiego omawiana rzeźba może być ludowa o reminescencjach gotyckich. Należałoby wyjaśnić według Mariana Korneckiego ewentualne drogi przejmowania owych reminescencji. Osąd ten należało po bliższej analizie odrzucić, abstrahując nawet od teoretycznych rozważań o kryteriach kwalifikacyjnych zaliczenia do tej kategorii twórczości, której w odległych stuleciach odmówiono racji istnienia w świetle historycznych uwarunkowań. Aspektu prymitywizmu nie można jednak pominąć. Rzeźba ta pochodzi z około połowy XIV wieku. Marian Kornecki utrzymuje tę datację powstania rzeźby. Wówczas obiekt zasługiwał na wyróżnienie na płaszczyźnie syntetycznego omówienia zasobów.

W zeszycie katalogu Zabytków Sztuki redaktorzy uściślili datowanie rzeźby na lata około 1360 - 1370. W opracowaniach naukowych brak informacji o twórcy tej rzeźby. Rzeźba podobnie jak kilka analogicznych, nie jest monolitem. Postać Marii, opracowana jako przyścienna, chociaż nie potraktowana reliefowo, jest od tyłu wydrążona przy użyciu dłuta. Zaniechanie drążenia górnej partii wywołało częściowe pęknięcie drewna. Postać Chrystusa jest rzeźbą pełną; zmontowana jest - z uwagi na kompozycję - z kilku fragmentów zespolonych przy użyciu kołeczków. Twórca nie starał się ukryć widocznych złączy. Postać siedzącej Marii, lekko przygarbionej, podtrzymuje na kolanach nagie, wychudzone ciało Chrystusa. Mimo jego pewnego, jakby proporcjonalnego pomniejszenia, nie jest to w żadnym wypadku wariant pośredni w stosunku do typu Piety corpusculum (gdzie ciało Chrystusa świadomie silnie pomniejszono, w ideowym sensie przedstawienia boleści Matki opłakującej swe dziecko). Chrystus, ukazany w postaci siedzącej, z dość sztywnym układem głowy, posiada charakterystyczny układ rąk: prawą bezwładnie zwisającą i lewą wspartą na ręce Marii. Uwagę zwracają równolegle ułożone nogi, z jakby nienaturalnie wydłużonymi stopami. Aby ograniczyć się do istotnych szczegółów, trzeba dostrzec „,narzucone” na uda perizonium, układające się w miękkie i finezyjne fałdowanie. Ważne jest również potraktowanie głowy Marii, o pogrubionych, zdawać by się mogło, niedopracowanych rysach twarzy, o bolesnym wyrazie ( co sygnalizują pionowe zmarszczki na czole) i odsłoniętych, słabo rzeźbiarsko zaakcentowanych, gładkich włosach. Nie przeprowadzono jeszcze badań dotyczących polichromii tej rzeźby.

Wiedza o wyobrażeniu plastycznym Piety, sferze ideowej, historii pojawienia się w sztuce średniowiecza oraz rozpowszechnienia tego wizerunku jest obszerna i wszechstronnie opracowana. Autorzy polscy mają w nią poważny wkład i temat ten doczekał się bogatej bibliografii. Rzeźba z Witkowic prezentuje problematykę szczególną, o zaskakujących możliwościach porównawczych. Istotne będzie zatem stwierdzenie, że niełatwo zaszeregować Pietę z Witkowic w kręgu rzeźby gotyckiej w Polsce. Fundamentalny dla Małopolski korpus rzeźby gotyckiej sprzed połowy XV wieku opracowany został przez Józefa Edwarda Dutkiewicza, nie ukazuje bliskich odpowiedników, zresztą ciąg rozwojowy rozpoczynają tu słynne Piety corpusculum z Wojnicza i Biecza, do których nawiązują inne zabytki poprzedzające przełom stylowy około roku 1400. Podobne obserwacje można po- 
czynić także w innych środowiskach. Zabytek ten można skonfrontować ze śląskimi Pietami. Witkowicka Pieta, abstrahując od jej cech prymitywnych, znajduje liczne istotne pokrewieństwa w kręgu sztuki zachodniej, i to wśród dzieł stanowiących bezsprzecznie fundamentalne wzorce o uniwersalistycznym znaczeniu. Witkowicką Pietę można skonfrontować z kręgiem Piet „monumentalnych” typu diagonalnego (zwanego niekiedy heroicznym), o szczególnym napięciu dramatyzmu, które zapoczątkowują drogę przemian ideowych i formalnych. Porównywać można nie tylko ogólną kompozycję układu, ale też niektóre drobniejsze szczegóły, jakie nie mogły pojawić się przypadkowo czy spontanicznie. Uchodzące może za najstarsze, datowane niekiedy na około 1300 rok rzeźby, jak Pieta z Zurychu czy słynna Pieta „radosna” z Ruggisberg (abstrahując od jej określenia) - ukazują ów ściśle diagonalny, analogiczny układ postaci, różniący się tylko sztywnym, ukośnym zakomponowaniem prawej ręki Chrystusa, podczas gdy inne szczegóły są podobne. Szczególnie charakterystyczny jest też układ nóg z płaskimi, wydłużonymi stopami, a także narzucone na uda perizonium. Dalsze podobieństwa odnajdujemy w kręgu słynnych Piet: z Bonn (około 1300 rok), z klasztoru Urszulanek w Erfurcie ( początek XIV wieku) czy z Salmdorf, w pobliżu Monachium (około 1330 rok), gdzie różnica układu postaci to bezwładnie odchylona głowa Chrystusa. Właśnie te cechy niejako kulminują się w może najsłynniejszym dziele - rzeźbie z Veste Coburg, w Górnej Frankonii, pochodzącej z Scheuerfeld, uznawanej za dzieło wzorcowe, w którym widzi się najwyższe osiągnięcie artystyczne i które - jak sugeruje W. Pinder - ukazuje „monumentalność sztuki katedralnej”. Stąd już blisko do znakomitej i równie podręcznikowej Piety z Lubiąża. Znajduje się ona obecnie w Muzeum Narodowym w Warszawie. Pieta ta zaliczana jest do czterech najstarszych Piet z XIV wieku, czy do reprezentacyjnej dla Górnych Węgier ( dziś Słowacji) Piety z Lipian (ok. 1360 - 1370), o wysokich walorach estetycznych. Obok tego monumentalnego nurtu, wiążącego Piety z Veste Coburg z rzeźbą lubiąską, na Górnym Śląsku są jeszcze co najmniej dwie rzeźby o owym szczególnym dramatycznym napięciu, górującym nad czynnikiem estetyzacji. Takim przykładem jest Pieta z Siemysłowa. Została ona opisana na początku lat sześćdziesiątych przez Mariana Korneckiego i Tadeusza Chrzanowskiego w kapliczce przydrożnej (po roku 1965 roku w miejscowym kościele).

Z materiałów źródłowych (archiwaliów) wynika, że pochodziła $\mathrm{z}$ fary w Namysłowie. Rzeźba ta, mimo ewidentnej różnicy warsztatowej, wydaje się bardzo bliska witkowickiej Piecie. I wreszcie ten nurt dramatyczny silnie akcentuje Pieta z Luboszyc (która była inwentaryzowana w kapliczce cmentarnej w Zawadzie, później została przeniesiona do luboszyckiego kościoła). Może ta rzeźba będzie przykładem zanikania nurtu dramatycznych Piet przed ich przetworzeniem w kompozycje „liryczne” przełomu XIV i XV wieku. Wskazane w artykule konfrontacje są tylko wybiórczymi próbami zmierzającymi do umiejscowienia witkowickiej Piety na widowni snycerstwa gotyckiego. Przykładów akcentujących podobieństwa i różnice w stosunku do wielu jeszcze zabytków można mnożyć. Według Mariana Korneckiego ta „drugorzędna”, prymitywna Pieta, zniesiona przed laty ze strychu drewnianego kościółka, przenosi nas w atmosferę głębi średniowiecza, z całym „bagażem” - ideowym, formalnym i w końcu artystycznym. 
Rzeźba ta - na szerokiej płaszczyźnie gotyckich zabytków Małopolski, ale nie tylko, bo jak się okazuje, jej analiza sięga nader szerokich horyzontów - zajmuje miejsce szczególne. ${ }^{43}$

Przykładem nurtu, w którym przejawia się ogromne napięcie dramatyzmu, przywodzące na myśl południowoniemieckie i śląskie ( Pieta z Lubiąża), pełne ekspresji i wstrząsające ujęcie tematu Opłakiwania, jest nie znana do niedawna dużych rozmiarów Pieta w Witkowicach. Zwraca w niej uwagę kubistyczna postać Marii i niesamowite, wychudzone ciało martwego Chrystusa, z charakterystyczną, bezwładnie opadającą ręką. Rzeźba ta, mimo grubego, wybitnie prymitywnego opracowania, wykazuje cechy stylu połowy XIV wieku. ${ }^{44}$

\section{Pieta w Kościele pod wezwaniem Narodzenia Najświętszej Marii Panny w Czchowie}

Rzeźba Matki Boskiej w typie zwanym „Pieta” znajdowała się aż do roku 1962 w kapliczce na niedalekim Zapotoczu. Jednak po kradzieży innej rzeźby gotyckiej - św. Anny Samotrzeć - przeniesiono tę figurę po niezbędnej konserwacji do bocznego ołtarza w nawie kościoła. ${ }^{45}$

W aktach parafii Czchów są dwie wzmianki informujące o powstaniu kapliczki, w której mieści się rzeźba. Z akt parafii Czchów wynika, że kapliczka, w której znajdowała się rzeźba została wzniesiona w 1977 roku z fundacji Marii Poślińskiej. Jest to gipsowa statua Najświętszej Panny Marii Niepokalanie Poczętej, mieszcząca się na betonowym postumencie, wykładanym kamyczkami rzecznymi w ozdobnej osłonie metalowej. ${ }^{46} \mathrm{Z}$ innych akt parafii wynika, że kapliczka została wzniesiona w XVIII wieku. Jest murowana, z kamienia, prostokątna, otynkowana i kryta dachówką. Dach kapliczki jest z okapem od frontu. Drzwi od jej wejścia są płycinowe z drewnianą kratą. Wewnątrz na ołtarzyku znajduje się gipsowa figurka Najświętszej Panny Marii Różańcowej. Ponadto znajduje się tam drewniana pasyjka z XIX wieku oraz gipsowa figurka Najświętszej Marii Niepokalanie poczętej i oleodruki Serca Jezusa i św. Antoniego. W tej kapliczce przechowywano gotycką rzeźbę matki Boskiej Bolesnej z połowy wieku XV. Obecnie rzeźba mieści się w kościele parafialnym i na plebanii. ${ }^{47}$

Rzeźba ta powstała w pierwszych latach wieku XV. Figura ta została wykonana $\mathrm{z}$ jednolitego pnia drzewa lipowego. Jest to figura przyścienna, wewnątrz wy-

${ }^{43}$ M. Kornecki, Średniowieczna Pieta z Witkowic, w: Teki Krakowskie V, red. S. Kołodziejski, R. Marciniak, Kraków 1997, s. 82-85.

${ }^{44}$ Chrzanowski, Kornecki, Sztuka, s. 109.

${ }^{45}$ Z. Kogut, Galeria Madonn z Dzieciątkiem w Muzeum Diecezjalnym w Tarnowie, Tarnów 1987, s. 90 (mpis, Biblioteka Wyższego Seminarium Duchownego w Tarnowie)

${ }^{46} \mathrm{AD}$ w Tarnowie, zespół:Akta lokalne (parafialne), Dekanat: Czchów, Parafia Czchów, sygn. LCXIII, Parafia Czchów, k. 1.

${ }^{47}$ AD w Tarnowie, zespół: Akta lokalne (parafialne), Dekanat Czchów, Parafia Czchów, sygn. LCXIII, Zapoznanie, k. 71. 
drążona, o wysokości $67 \mathrm{~cm}$. Stan tej rzeźby jest dobry. ${ }^{48}$ Anonimowy artysta przedstawił Matkę Boską w ujęciu frontalnym, siedzącą na ławie i trzymającą w ramionach martwe ciało Syna. Prawą ręką podtrzymuje głowę Chrystusa spoczywającego na jej kolanach, lewą zaś ujmuje złożone dłonie Chrystusa. ${ }^{49}$

Jest pierwszym z okazów przejściowych od monumentalnych, wyobrażeniowych przedstawień tego tematu do kameralnych w naturalistycznym ujęciu. Forma rzeźby rozwija się przestrzennie w głąb, a sposób jej opracowania świadczy o pojmowaniu przedmiotu w kategoriach widzenia naturalistycznego. W surowym obliczu bolejącej Matki brak jeszcze wyrazu ckliwej sentymentalności, tak typowej dla Piet śląskich pierwszych lat wieku XV. ${ }^{50}$

Fałdy szat rozczłonkowują się naturalnie, co tworzy zróżnicowaną grę powierzchni i bogatą skalę wgłębien ${ }^{51}$ Zbliża się ona pod tym względem do niektórych przykładów reprezentowanych na północy przez Opłakiwania ze Świerczynek i Lidzbarka na Pomorzu i Warmii, a na Śląsku w pewnym stopniu przez figury z Bukowa koło Strzegomia i z kościoła św. Doroty we Wrocławiu. ${ }^{52}$

Należałoby podkreślić, że równie popularne przedstawienie Opłakiwania, czyli Pieta, rozpowszechnione w oparciu o teksty apokryficzne i wiążące się z nurtem mistycznym, rozpowszechniło się poza potrzebami liturgii dla celów indywidualnego kultu, nie bez silnej inicjatywy żeńskich środowisk. ${ }^{53}$

\section{Pieta ze Szczyrzyca}

Równie ciekawym obiektem jest Pieta ze Szczyrzyca, początkowo uważana za XVII - wieczną rzeźbę. Podczas konserwacji, po ściągnięciu zniszczonej polichromii, okazało się, że rzeźba ta jest znacznie starsza. ${ }^{54}$ Powstała około 1450 1460. Dzieje rzeźby nie zostały dotąd źródłowo udokumentowane, a pochodzenie pozostaje niepewne. Odmienność stylistyczna figury w stosunku do dzieł małopolskich nasuwa wątpliwości co do jej pochodzenia. Niewątpliwie jest to import, nie ma jednak pewności, czy dzieło to trafiło do szczyrzyckich cystersów już w XV wieku. Być może, podobnie jak krucyfiks z około 1440 roku. Pieta należy do niewielu elementów wyposażenia, które przetrwały pożar szczyrzyckiej świątyni w 1765 roku i zostały przeniesione na klasztorne krużganki. Należy podkreślić, że część dzieł przechowywanych obecnie w szczyrzyckich zbiorach znalazła się tam dopiero po 1945 roku. Niektóre przeniesiono w latach pięćdziesiątych XX wieku z klasztoru Cystersów w Henrykowie. Niewykluczone, że ta Pietá została przeniesiona do Małopolski z jednego z kościołów filialnych Henrykowa lub też

${ }^{48}$ J. E. Dutkiewicz, Małopolska rzeźba średniowieczna 1300-1450, Kraków 1949, s. 118.

${ }^{49}$ Kogut, Galeria Madonn, s. 90

${ }^{50}$ Dutkiewicz, Małopolska rzeźba, s. 118.

${ }^{51}$ Kogut, Galeria Madonn, s. 90.

${ }^{52}$ Dutkiewicz, Małopolska rzeźba, s. 118.

${ }^{53}$ Chrzanowski, Kornecki, Sztuka, s. 107-108.

${ }^{54}$ P. Droździk, M. Wcześny, Opactwo Cystersów w Szczyrzycu, Nowy Sącz 2004, s. 12. 
z samej świątyni klasztornej na Dolnym Śląsku. Odkryte na nowo, dzięki konserwacji, wysokiej klasy dzieło wymaga niewątpliwie szczegółowych badań, zarówno stylistycznych, jak i archiwalnych. ${ }^{55} \mathrm{~W}$ aktach z miejscowości Szczyrzyc w Archiwum Diecezjalnym w Tarnowie nie ma informacji o pochodzeniu, dziejach i wizerunku tej Piety. W 2003 roku Pietá została poddana konserwacji w pracowni Magdaleny i Stanisława Stawowiaków. W trakcie prac usunięto wtórne przemalowania, odkrywając pierwotną, dobrze zachowaną polichromię. Polichromię scalono, uzupełniono palce lewej dłoni Chrystusa i odcięty czubek jego głowy (fragment głowy przerobiono niegdyś tak, aby mieściła się w niszy). Jest to rzeźba przyścienna, o głębokości $17 \mathrm{~cm}$, przedstawia siedzącą na ławie Marię trzymającą na kolanach ciało Syna. Wyprostowana postać Matki Boskiej ukazana jest frontalnie. Prawą ręką podtrzymuje plecy Chrystusa, lewą ujmuje jego bezwładną rękę, ukazując ciało widzowi. Druga ręka Jezusa opada ku ziemi. Maria ubrana jest w czerwoną suknię oraz okrywający ramiona i nogi biały płaszcz ozdobiony motywem srebrnych rombów obwiedzionych podwójną czerwoną linią z półokrągłymi wypustkami i złotą bordiurą. $U$ dołu szata odwija się, odsłaniając błękitną podszewkę. Głowę Marii spowijają srebrna, okolona złotym rantem chusta i podwika o nierównej fakturze imitującej grubo tkany materiał.

Pietá reprezentuje typ wywodzący się ze sztuki Niderlandów i Nadrenii. Inaczej niż w wypadku Piet stylu pięknego, opadające bezwładnie ciało Chrystusa jest przez Marię odwracane w kierunku widza, prezentowane wiernemu. Ekspresja omawianej rzeźby wynika przede wszystkim z przemyślanego ujęcia gestów i mimiki twarzy. W opracowaniu szat natomiast wyraźne jest wyciszenie, rezygnacja $z$ efektownych rozwiązań. Godne zauważenia jest współgranie pełnego wyrazu modelunku i polichromii. Uwaga skupiona została na bólu Marii. Jej duże, opuchnięte oczy ustawione są ukośnie, a w ich kącikach rysują się drobne zmarszczki. Maria unosi dramatycznie brwi, marszczy czoło. Ma skrzywione asymetrycznie usta. Mistrzowsko oddanemu bolesnemu wyrazowi twarzy towarzyszy podkreślająca go polichromia: skóra wokół oczu, na policzkach i brodzie zaczerwieniona jest od płaczu, a twarz - pobladła. Ciało Chrystusa, osłonięte krótkim, srebrnym perizonium, odznacza się plastycznym modelunkiem mięśni, natomiast twarz jest bardziej idealizowana, bliższa tradycji rzeźby około 1400 roku. Karnacja Chrystusa ma chłodniejszy odcień. O jego śmierci świadczą sine cienie na paznokciach dłoni i stóp, wokół ran oraz zaznaczone żyły. Ślady krwi widoczne są tylko wokół czoła i skroni oraz ran.

Naturalny, miękki układ szat marszczących się właściwie jedynie u dołu wskazuje na czas powstania rzeźby około 1450 - 1460. Takiego datowania nie wyklucza kolorystyka szat Marii - biały płaszcz z rozrzuconym luźno geometrycznym wzorem - charakterystyczna raczej dla pierwszej połowy wieku XV (np. śląska Pieta z około $1430 \mathrm{w}$ zbiorach Muzeum Narodowego w Warszawie). Wskazać można zebrane przez Bartlową przykłady podobnych rozwiązań z połowy XV stulecia w takich rzeźbach jak: Madonna Krügera z kręgu Mistrza z Seoon

${ }^{55}$ D. Horzela, Między liryzmem a ekspresja - rzeźba w Małopolsce przed Witem Stwoszem 1450-1477, w: Wokót Wita Stwosza. Katalog wystawy w Muzeum Narodowym w Krakowie, red. K. Stefaniak, Kraków 2005, s. 37-39. 
( ok. 1440 - 1445; Innsbruck, Landesmuseum Ferdinandeum), figury z nastawy z Wiener Neustadt ( 1447 r.; katedra św. Szczepana w Wiedniu), Pieta z Litomierzyc (ok. $145 \mathrm{O}$ r.; Galeria Narodowa w Pradze), figura Marii z Dzieciątkiem z klasztoru Franciszkanów w Pilźnie z około 1450 roku.

Wśród zachowanych w Małopolsce rzeźbionych Piet tego czasu można znaleźć jedną o podobnej ekspresji. Jest to rzeźba przechowywana w Muzeum Uniwersytetu Jagiellońskiego. Rzeźby te łączy niemal taka sama kompozycja, a także podobieństwo fizjonomii Marii. Wydaje się, że figury powstały w tym samym środowisku i w zbliżonym czasie. Niestety, pochodzenie - zakupionej w antykwariacie po 1945 roku - rzeźby ze zbiorów Uniwersytetu nie jest znane. ${ }^{56}$

\section{Pieta z Dobczyc}

Rzeźba pochodzi zapewne z nieistniejącego, średniowiecznego kościoła parafialnego św. Jana Chrzciciela w Dobczycach. ${ }^{57}$ Józef Dutkiewicz tak pisał o odnalezieniu tej rzeźby: „W nowoczesnym kościele parafialnym w Dobczycach udało się odnaleźć w bocznym ołtarzu rzeźbę drewnianą. Pochodzi z dawnego kościoła na górze, przedstawia Zdjęcie z Krzyża. Poza zdobyciem ewidencji samego obiektu nie poszczęściło się jednak, jak zwykle, pozyskać obszerniejszych wiadomości czy materiałów. O grupie z Dobczyc trudno powiedzieć coś zdecydowanego". ${ }^{58}$ Pieta powstała około 1500 roku lub na początku XVI wieku. Józef Dutkiewicz porównywał ją z kilkoma Pietami śląskimi i południowoniemieckimi, datując na lata $1510-1520$. W Katalogu zabytków sztuki w Polsce datowana była na pierwszą ćwierć XVI wieku. Olszewski wskazał na podobieństwo do dzieł Tilmana Riemenschneidera (między innymi Pieta w Hassenbach, Opłakiwanie Chrystusa w Germanisches Nationalmuseum w Norymberdze) i Petera Breuera (Pietá w kościele Mariackim w Zwickau), datując rzeźbę na koniec wieku XV lub początek XVI wieku. Marian Kornecki podkreślał nowatorstwo kompozycji i wysoki poziom artystyczny rzeźby, która miała powstać „w bliskości warsztatu Stwosza” na początku wieku XVI. Ostatnio podobnie była datowana przez Włodarka. Natomiast Józef Edward Dutkiewicz wysnuł zbliżone wnioski o pochodzeniu tej rzeźby z własnych obserwacji. Badacz tak pisał o Piecie w artykule pt. Nieznane rzeźby XIV - XVI wieku na terenie Małopolski Południowo - Zachodniej”: „Również gestykulacja i opracowanie rąk nasuwają podobne refleksje. Obserwacja rzeźby charakteryzowałaby pewien kompleks uczuciowy snycerza, kompleks prosty, który nie wskazywałby na pochodzenie $\mathrm{z}$ większego środowiska. Jeśli z kolei zwrócić uwagę na szczegóły stylistyczne, tak pozornie bliskie popularnie zwanej maniery stwoszowskiej, to obserwacje powyższe znajdą nowe uzasadnienie

\footnotetext{
${ }^{56}$ Tamże.

${ }^{57}$ W. Walanus, Wit Stwosz a późnogotycka rzeźba w Małopolsce - zarys problematyki, w: Wokót Wita Stwosza. Katalog wystawy w Muzeum Narodowym w Krakowie, red. K. Stefaniak, Kraków 2005, s. 129.

${ }^{58}$ J. Dutkiewicz, Nieznane rzeźby XIV - XV wieku na terenie Małopolski Poludniowo - Zachodniej, „Biuletyn Historii Sztuki i Kultury”, 2 (1934) nr 4, s. 261.
} 
w twierdzeniu, że grupa z Dobczyc daleka jest od środowiska krakowskiego i stwoszowskiego i że, jak świadczą znaczne uproszczenia, a nawet nieporozumienia, w formułowaniu układu figur i wymowy fałdów, pochodzi ona $\mathrm{z}$ warsztatu prowincjonalnego, w którym odbijały się jedynie dalekie refleksy zarówno środowiska krakowskiego jak i innych środowisk dalszych".

Rzeźba trafiła później do dziewiętnastowiecznej drewnianej kaplicy, zastąpionej w latach 1948- 1949 obecnym murowanym kościołem. Była konserwowana w latach 1960-1961 (A. Stawarz, Kraków), w latach 1986 i 1987 (K. Witkowska). Zdjęto przemalowania rzeźby. Wykonano rekonstrukcję brakujących elementów (stopy Chrystusa, palce u rąk) polichromii. ${ }^{59}$

Jest to rzeźba o wysokości $1 \mathrm{~m}$, wykonana jest z drzewa lipowego. Jej polichromia odzwierciedlała różne kolory: biały, szary, niebieski, czerwony, złoty. Polichromia wyróżniała się także kolorem o blado - różowej karnacji ${ }^{60}$ Rzeźba w Dobczycach jest jedynym znanym w Małopolsce przykładem takiego typu Piety, w którym Maria przyklęka na jedno kolano, a ciało Chrystusa spoczywa, półleżąc na podstawie ( $\mathrm{z}$ reguły na płaszczu Marii), podparte częściowo drugim kolanem Matki. Prawa dłoń rzeźby dotyka włosów Syna, lewą podnosi fragment draperii, by otrzeć swe oczy. Kompozycja ta znana była w rzeźbie niemieckiej już $\mathrm{w}$ połowie wieku $\mathrm{XV}$, a rozpowszechniła się w końcu tego stulecia. $\mathrm{W}$ ramach tego schematu możliwe są rozmaite warianty układu rąk i nóg Chrystusa oraz gestów Marii. Wsparty na kolanie Matki tułów Chrystusa ukazany jest frontalnie, ręce ułożone są wzdłuż ciała, a nogi odgięte w tył. Obie twarze są pełne wyrazu: rysy Marii zastygły w bólu, a w obliczu Chrystusa widać znamiona przebytego cierpienia. W Dobczycach obie ręce Zbawiciela ułożone są blisko ciała, co rzeczywiście zbliża małopolską grupę do Piety w kościele parafialnym w Hassenbach, wczesnego dzieła Riemenschneidera (około roku 1490), a także - w większym stopniu - do jego Opłakiwania Chrystusa w Germanisches Nationalmuseum (około 1505-1510). Układ ten był często powtarzany przez naśladowców würzburskiego mistrza. Z kolei występujący w Piecie dobczyckiej gest Marii, unoszącej rąbek chusty w celu otarcia oczu, można zaobserwować we wspomnianym dziele Breuera (około roku 1502), lecz to zbyt mało, by doszukiwać się jakichś bliższych związków obu rzeźb. ${ }^{61}$

Józef Edward Dutkiewicz zinterpretował wizerunek tej Piety. Pisał o niej: „W przedstawieniu wielkiego dramatu nie brak akcentów mocnych. Znamienną jest zwłaszcza pierwszoplanowa, realistyczna interpretacja zgonu Chrystusa, który wyrażono ze zdumiewającym znawstwem anatomii ciała i jego funkcji i reakcji fizjologicznych. Niemniej w drugoplanowej postaci Madonny wprowadzono akcenty, które manifestują posługiwanie się środkami ludowymi w osiąganiu efektów mimicznych." 62

${ }^{59}$ Walanus, Wit Stwosz, s. 129; W. Walanus, Późnogotycka rzeźba drewniana w Małopolsce 1490-1540, Kraków 2006, s. 198-199, Dutkiewicz, Nieznane rzeźby, s. 261.

${ }^{60}$ Dutkiewicz, Nieznane rzeźby, s. 261.

${ }^{61}$ Walanus, Wit Stwosz, s. 129-130, Walanus, Późnogotycka rzeźba, s. 199-200.

${ }^{62}$ Dutkiewicz, Nieznane rzeźby, s. 261. 
Najbardziej charakterystyczną cechą Piety w Dobczycach jest rozwinięcie kompozycji w przestrzeni poprzez ułożenie ciała Chrystusa w ten sposób, że otacza ono figurę Marii - jego nogi są wyraźnie odgięte do tyłu. Rzeźba zwiększa dzięki temu swój wolumen, co skłania widza do oglądania jej z kilku stron, zupełnie inaczej niż w przypadku dzieł Riemenschneidera, obliczonych raczej na widok frontalny. Pod tym względem Pieta w Dobczycach pokrewna jest dziełom działającego w Norymberdze warsztatu, którego dziełem jest tzw. retabulum Peringsdörfferów (1486 rok.) w kościele Pokoju w tym mieście. W latach 1485 $1490 \mathrm{w}$ warsztacie tym powstała grupa Opłakiwania Chrystusa (tzw. Wielka Pieta w kościele św. Jakuba w Norymberdze), której rozbudowana przestrzennie, wielowidokowa bryła otoczona jest wygiętym ciałem Chrystusa. Naturalnie kompozycje rzeźb w Dobczycach i Norymberdze są zdecydowanie odmienne (co wynika choćby z różnicy tematów), można jednak odnotować podobny, półkolisty kształt podstawy w obu grupach. Pod wpływem Opłakiwania w kościele św. Jakuba powstała Pieta w klasztorze franciszkanów w Pilznie, uważana za import z Norymbergii (koniec wieku XV). Także i w tym dziele zastosowano zasadę przestrzennego otoczenia Marii ułożonym diagonalnie ciałem Jezusa. Pieta w Dobczycach prezentuje niewątpliwie zredukowany wariant tej zasady - podstawą kompozycji pozostał opisany powyżej, częściej spotykany w rzeźbie niemieckiej schemat upozowania ciała Chrystusa. Z kolei użycie „Riemenschneiderowskiego" układu rąk Chrystusa przyczyniło się do osłabienia dynamiki grupy.

Natomiast Józef Edward Dutkiewicz pisał o analogiach tej rzeźby ze środowiskiem śląskim. Pisał o Piecie: „Nie podobna tu pominąć środowiska śląskiego, w którym grupa dobczycka znajduje najwięcej analogii takich, jak sceny ze Zdjęciem z Krzyża ( Vesperbild): w Stoschendorf Katherinenkirche, Patschkau - Katherinenkirche, Bockau Katherinenkirche), Gross - Osten Kath. Kirche). Typ śląski był uzależniony od południowych Niemiec, gdzie znajdują się rozwiązania tego samego typu (Obermachtel). Analogie jak i walory stylistyczne wyznaczają grupie Zdjęcie z Krzyża z Dobczyc lata powstania na około 1510 - 1520.

Mimo tych zastrzeżeń przyjąć trzeba, że twórca Piety dobczyckiej zapoznał się $\mathrm{z}$ autopsji z dziełami wspomnianej norymberskiej pracowni. Zapewne znane mu były także dzieła podobne do wymienionych rzeźb Riemenschneidera. Swój osobisty styl anonimowy snycerz wyraził przede wszystkim w ekspresyjnym kształtowaniu ciała Chrystusa, przy zachowaniu zasadniczej zgodności z anatomią: klatka piersiowa jest mocno uwypuklona, wyraźnie zaakcentowane są mięśnie, żebra i potężna muskulatura nóg. Uwagę widza przyciągają ręce, poorane nabrzmiałymi naczyniami krwionośnymi. Ten daleki od realizmu sposób modelunku zbliża dzieło małopolskie do reliefu św. Jana Chrzciciela na puszczy, pochodzącego z Wrocławia ( 1499 rok, obecnie w kościele parafialnym w Cieszynie Wielkopolskim). Widoczne spod meloty prawa ręka i noga proroka wykazują podobną stylizację żył, odchodzącą od poprawności anatomicznej, za to zmierzającą ku większej sile wyrazu. Formy reliefu śląskiego wiążą się przede wszystkim z oddziaływaniem sztuki Wita Stwosza. Dla opracowania obnażonej nogi św. Jana źródłem inspiracji mogły być dzieła w rodzaju niewielkiego krucyfiksu w Muzeum Narodowym w Krakowie. Wydaje się, że ekspresyjne tendencje widoczne 
w kształtowaniu ciała Chrystusa w Piecie dobczyckiej mogą także być wynikiem zetknięcia się jej twórcy ze stylem wielkiego rzeźbiarza. ${ }^{63}$

Dzięki dokonanej przeze mnie kwerendzie wybranych akt archiwalnych parafii (Limanowa, Wojnicz, Czchów) oraz analizie informacji z opracowań naukowych mogę skonstatować, że moje ustalenia dotyczące wieku powstania Piety z Limanowej, Wojnicza i Czchowa zawarte w tym artykule są zgodne $\mathrm{z}$ dokonanymi przez Józefa Edwarda Dutkiewicza badaniami naukowymi.

W tym miejscu należałoby także potwierdzić ustalenia dokonane przez innych badaczy Limanowskiej Piety, zwłaszcza te, które dotyczą jej pochodzenia, dziejów i wizerunku ( Józef Szymon Wroński, biskup Piotr Bednarczyk, ksiądz Ludwik Kowalski). Dotychczas nie ustalono twórców omawianych Piet, są nieznani. W aktach parafii i miejscowości jest brak danych o twórcach omawianych powyżej Piet. Tylko Józef Edward Dutkiewicz przypuszczał, że rzeźby takie jak: Pieta z Wojnicza, Pieta z Biecza (Opłakiwanie II) powstały dzięki snycerzom. Nie podawał konkretnych imion i nazwisk twórców Piet omawianych w opracowaniu pt. „Małopolska rzeźba średniowieczna 1300 - 1450”. Podał tylko przypuszczenie (wzmiankę), że Pietę z Biecza mógł wykonać snycerz ze Śląska lub Pomorza. Prawie wszystkie opisane Piety wykazują podobieństwa z rzeźbami z kręgu niemieckiego. Tylko Pieta z Czchowa i i Pieta z dawnego Szpitala Ubogich w Bieczu nie wykazują podobieństw z kręgiem rzeźb niemieckich. Analogie w wizerunku z rzeźbą niemiecką wykazują dwie tylko Piety: Pieta z dawnego Szpitala Ubogich w Bieczu i Pieta z Wojnicza. Pokrewieństwo z rzeźbą niemiecką wykazują takie Piety jak: Pieta limanowska, Pieta z Dobczyc, Pieta z Witkowic. W niewielkim stopniu tylko Pieta $\mathrm{z}$ Wojnicza wykazuje różnice w wizerunku z najstarszymi rzeźbami saskimi (Opłakiwania saskie) w zakresie swobodniejszego ukształtowania przestrzennego, miękkiego traktowania form i fałdów. Poza tym szereg tych rzeźb wykazuje podobieństwa w zakresie wizerunku ze środowiskiem śląskim. Podobieństwa takie wykazują w szczególności takie Piety jak: Pieta z Biecza (Opłakiwanie II), Pieta Limanowska (cechy), Pieta w Kościele pod wezwaniem Narodzenia Najświętszej Marii Panny w Czchowie (w zakresie fałdów szat), Pieta $z$ Witkowic ( ukazanie napięcia dramatyzmu w rzeźbie), Pieta ze Szczyrzyca (w zakresie kolorystyki szat - płaszcz z geometrycznym wzorem), Pieta z Dobczyc. Analogie ze śląską rzeźbą wykazywała tylko Pieta z Dobczyc. Tylko trzy małopolskie, gotyckie Piety wykazywały między sobą podobieństwa w wizerunku. Pieta $z$ dawnego Szpitala Ubogich w Bieczu wykazywała podobieństwo $w$ wizerunku $\mathrm{z}$ Pietą $\mathrm{z}$ Wojnicza (w zakresie części figury), a Pieta z Biecza nawiązywała swoim wizerunkiem do rzeźb z powiatu limanowskiego i Limanowej i klasztoru klarysek krakowskich. Jednak należałoby stwierdzić, że większość Piet z Małopolski z okresu średniowiecza wykazywała raczej więcej podobieństw niż różnic $\mathrm{i}$ analogii $\mathrm{w}$ ich wizerunku.

\footnotetext{
${ }^{63}$ Walanus, Późnogotycka rzeźba, s. 200-202, Dutkiewicz, Nieznane rzeźby, s. 262.
} 


\title{
THE CHOSEN PIETÀS IN LITTLE POLAND FROM THE MIDDLE AGES- THEIR PROVENANCE, HISTORY AND IMAGE
}

\begin{abstract}
Summary
The main purpose of this work is to present the provenance and the history of the chosen, characteristic and famous Pietàs from different works of art, monuments, and other buildings- for instance, churches, hospitals and roadside shrines. The vital issue of this article is to show the outward image of Pietàs. The author also focuses on analogies, similarities and differences in the image of Pietàs from Little Poland, and other regions and places which were outside Poland in the Middle Ages. This work concentrates only on the chosen Pietàs from different places such as Pietà from Limanów, Pietà in the church of the Nativity of the Holy Virgin Mary in Czchów, Pietà from Wojnicz, Pietà from Biecz (Mourning II), Pietà from the former Hospital for the Poor in Biecz, Pietà from Witkowice, Pietà from Szczyrzyc, Pietà from Dobczyce.

The author chose these Pietàs, which despite coming from different places of Little Poland in the Middle Ages, best illustrate similarities and differences between each other and other sculptures. The paper also compares the analysed Pietàs with various sculptures and Pietàs from other regions of Poland and outside the country.

Only certain of Pietàs are presented in this article, especially these which are described in different academic works and source materials. Some academic papers lack detailed information about the provenance, the history and the image of some of the gothic Pietàs from the Middle Ages in Little Poland. Only Pietà from Limanowa is the one about which there is thorough information in academic papers and source materials.

So far, there has been no synthetic work or article about the provenance, the history and the overall image of Pietàs from Little Poland in the Middle Ages.
\end{abstract}

Translated by Aneta Kiper 